
\title{
Research Suare \\ Exploring the historical distribution of Dracaena cinnabari using ethnobotanical knowledge on Socotra Island, Yemen
}

Abdulraqeb Shamsan Al-Okaishi ( $\sim$ abdulraqeb07@yahoo.com )

Faculty of Forestry and Wood Technology, Mendel University in Brno

Research

Keywords: Ethnobotany, Toponymy, Phytotoponym, Socotra Island, dum al-akhawin, Dragon's Blood Tree

Posted Date: January 28th, 2021

DOl: https://doi.org/10.21203/rs.3.rs-153442/v1

License: (c) (i) This work is licensed under a Creative Commons Attribution 4.0 International License.

Read Full License

Version of Record: A version of this preprint was published at Journal of Ethnobiology and Ethnomedicine on April 1st, 2021. See the published version at https://doi.org/10.1186/s13002-02100452-1. 


\section{Abstract}

\section{Background}

In this study, we present and analyze toponyms referring to Socotra Island's endemic dragon's blood tree (Dracaena cinnabari) in four areas of the Socotra Archipelago UNESCO World Heritage site (Republic of Yemen). The motivation is understanding of the past distribution of $D$. cinnabari trees which is an important part of conservation efforts by using ethnobotanical data. We assumed that dragon's blood trees had a wider distribution on Socotra Island in the past.

\section{Methods}

This research was based on field surveys and interviews with the indigenous people. The place names (toponyms) were recorded in both, Arabic and indigenous Socotri language. We grouped all toponyms into five different categories according to the main descriptor: Terrain, Human, Plant, Water and NA (unknown). In addition, this study identified current and historical Arabic names of dragon's blood trees of the genus Dracaena, through literature review.

\section{Results}

A total of 301 toponyms were recorded from the four study areas in Socotra Island. Among names related to plants, we could attribute toponyms to nine different plant species, of which six names referred to the D. cinnabari tree, representing $14.63 \%$ of total phytotoponyms in the category. Three historical naming periods prior to 2000 could be identified. The most commonly used Arabic name for dragon's blood trees

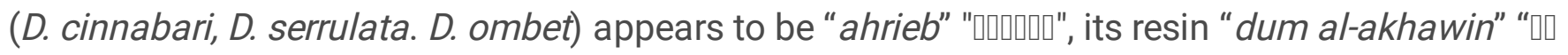

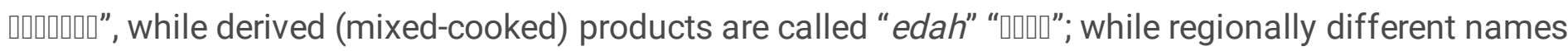
can be found.

\section{Conclusion}

The place names that refer to $D$. cinnabari are herein suggested to represent remnant areas of once large populations. The toponyms may therefore support known hypotheses based on climate models that $D$. cinnabari had a wider distribution on Socotra Island in the past. This study also confirmed the historical importance of dragon's blood

\section{Background}

\section{Ethnobotany and Toponymy}

Since the beginning of civilization, people have used plants for food, medicine, as well as materials for construction and the manufacture of crafts and many other products $\left[{ }^{1}\right]$. In addition, plants have extensive symbolic uses, such as in art, mythology and literature[ ${ }^{2}$ ]. Interactions between people and plants have accumulated large bodies of traditional ecological knowledge built by a group of people 
through generations living in close contact with nature. It includes a system of management of resources, classification and observations [3]. The term ethnobotany was designated by Harshberger (1896)[4], originally linked to the description of plants materials use by Aboriginal Australians. Ethnobotany later became a more ecological term, focusing on relationships, interrelationships, and interaction with a cultural perspective [5]. Harshberger (1896) $\left[{ }^{4}\right]$ considered that ethnobotany could also help in studying past distribution of plants.

People need to give names to areas to label, identify and locate them in space [ $\left.{ }^{6}\right]$. When the indigenous inhabitants give such names, they often use them for distinctive spatial orientation, landscape features, natural phenomena, fauna, flora, natural substances and names of tribes or important individuals $\left[{ }^{7}\right]$. Toponyms are conservative and although the language and wording may evolve, the roots of place names are not likely to be altered by changes in human activities in the landscape through time $\left.{ }^{8-10}\right]$. Toponyms can be easy to record and may provide useful information about the history of a land and its resources $\left[{ }^{11}\right]$. According to Berkes (1993) $\left[{ }^{12}\right]$ systematic meaning through toponyms, oral history and spiritual relationships form part of a dimension of traditional ecological knowledge. Place names may also reflect intensity of land use, the extent of traditional ecological knowledge and population density of the associated society $\left[{ }^{13}\right]$, historical-cultural environmental development $\left[{ }^{14}\right]$, settlement history $\left[{ }^{15}\right]$ and archaeology $\left[^{16}\right]$. They can be used for studying current environmental issues such as tracking recent climate changes and perceptions of those changes $\left[{ }^{17-19}\right]$, water issues $\left[{ }^{20}\right]$ and the climatic environment $\left[{ }^{21}\right]$. The systematic study of indigenous place names can be an approach to the mapping of ethnoecological knowledge and understanding of the evolution of the landscape [22]. Toponyms concerning plants (phytotoponyms) and animals (zootoponyms), named according to what people used to see in their everyday life, can be the indicators of the present, or former presence of certain species [ ${ }^{23-}$ 26].

Phytotoponyms may provide information on spatial locations, temporal information and landscape [ $\left.{ }^{27}\right]$ they have been used to study landscape ecology and botany $\left[{ }^{10}\right]$, vegetation cover and long-term vegetation degradation $\left[{ }^{28}\right]$. According to Cunningham et al. (2001) [ $\left.{ }^{11}\right]$ local knowledge may sometimes be the only evidence that remains where some plant species use to occur. Phytotoponyms, not just the common plant names, describe also the usage of the species as food, medicine, fabric or for other activities $\left[{ }^{29,30}\right]$, and their interaction with the surrounding environment $\left[{ }^{31,32}\right]$. Therefore, these specific types of place names can be used for the reconstruction of past events, specific vegetation or certain species $\left[{ }^{10,33-38}\right]$.

Socotra Island, the largest island of the Socotra Archipelago (Yemen), which is located at the crossroads between the Red Sea, Arabian Sea and the Indian Ocean, was recognized as a regional center of biodiversity. The Archipelago is rich in biodiversity with spectacular endemic species, more than $37 \%$ of plant species are endemic $\left[{ }^{39}\right]$, but also rich in traditions that conserve this biodiversity until today. The landscape changes over the last centuries and/or millennia have rarely been studied. Paleoclimate 
studies indicate wetter periods in the Holocene on Socotra [ $\left.{ }^{40,41}\right]$, however there is very little paleontological or data available for the reconstruction of historic and prehistoric landscapes on the island $\left[{ }^{42}\right]$. In the more recent past (decades to a century), landscape changes were investigated with relation to vegetation, using historical photographs [ $\left.{ }^{43}\right]$, using a combination of old aerial photographs, satellite images and repeated field measurements to study changes in population of Dracaenacinnabari and Boswellia elongata, respectively [44],. More recently, Rezende et al. (2020) $\left[{ }^{45}\right]$ studied land productivity on Socotra using NDVI derived from satellite images in the last 20 years, showing a highly dynamic system.

\section{Socotra and Dragon's blood}

The Socotra Dragon's Blood Tree (Dracaena cinnabari) is a flag-ship species of Socotra $\left[{ }^{46,47}\right]$. It was a very important tree in ancient times due to a historically highly prized product called dragon's blood, a red resin extracted for a wide range of uses including coloring and local medicine [ $\left.{ }^{39,48}\right]$. Some believe that the name Socotra could even be a derived from "Sukkatira" or contracted from "suq qatra", where suq is the Arabic word for "market" and qatra for "dragon's blood" [ $\left.{ }^{49,50}\right]$. The first who mentioned $D$. cinnabari resin was the unknown author of the Periplus of the Erythrean Sea around mid-first century AD, who called it "cinnabar" [ $\left.{ }^{51}\right]$. Dioscorides (90 AD mentioned the resin in his book "On Medical Material" as Kinnabari "cinnabari", brought from Africa [ $\left.{ }^{52}\right]$.

Names of dragon's blood tree and its resin have been recorded by old Arabic literatures $\left[{ }^{53-57}\right]$, by researchers who visited Socotra $\left[{ }^{49,58-61}\right]$ and recently by $\left[{ }^{39,62-64}\right]$.

Several local names for Dracaena may indicate the significance of the ethnobotanical knowledge as an important source of information which can be used for tracking the history of these names or link them to the land by studying place names (toponyms). The aim of this study is to use this ethnobotanical knowledge to explore the spatial distribution of toponyms related to Dracaena cinnabari tree and its potential as an information source to assess the past distribution of this unique flagship species on Socotra Island.

\section{Material And Methods}

\section{Study area}

\section{Study areas selection}

Four areas have been selected by overlapping of two maps belonging to different datasets. The first map contains the current distribution of $D$. cinnabari $\left[{ }^{47}\right]$ and second map the potential distribution of $D$. 
cinnabari according to its ecology $\left[{ }^{70}\right]$. The areas of the potential distribution that are not overlapped by the current distribution were selected for the study (Fig. 1).

\section{Data collection}

\section{Survey technique and toponyms meaning}

Fieldwork was carried out by visiting the areas and interviewing people resident in the area, collecting the places names and obtained the meaning directly on the spot in collaboration with a local guide. The meaning of the names was discussed in detail with the indigenous people. Positions of the places have been recorded by GPS. During the fieldwork three types of data were recorded 1) toponyms, 2) visual observation of existing $D$. cinnabari trees in nature, and 3 ) interview with the people about the area (in particular, the occurrence of $D$. cinnabari in the area). Three areas were visited personally (Hagher, Momi, Qataria) and due to logistic limitations, the place names for the fourth area (Ma'ala) were recorded through communication with local people. The place names recorded by fieldwork and remotely were then confirmed by sending them to other two residents to ensure the meaning. Local people also have been asked if there are any names related to the dragon's blood tree and its distribution. GIS ArcMap was used to plot the georeferenced toponyms for three areas (Hagher, Momi and Qataria) and those from Ma'ala by approximation. In addition, detailed literature review of Arabic and Western sources was carried out to investigate current and old names for dragon's blood trees and its resin. Somali names for $D$. ombet collected by direct communication with Mr. Ahmed Ibrahim Awale, and the same for Sudani names for $D$. ombet indirect communication with Dr. Iqbal Madani.

\section{Results}

\section{Tracking dragon's blood names through history}

From literature, we can distinguish three naming periods (Fig. 2). Variety of names for dragon's blood appear during the golden era in science in the Islamic Arabic world (ca. 800 - ca. 1500 AD). The last period represents the new western renaissance and scientific exploring missions especially from Europe. The described period in this study begins in the year $60 \mathrm{AD}$, with the appearance of the first name referred to dragon's blood, and ends in the year 2000 with the opening of Socotra to the outside world-the opening of Socotra International Airport. The horizontal oval shape shows that the naming was at close intervals, while the oblique oval shape indicates that the naming appeared at long intervals.

Table 1. Appearing of dragon's blood names (resin/tree) from 1st century AD - 2000 AD 


\begin{tabular}{|c|c|c|c|c|c|}
\hline No. & Author & Referred to & Dragon's blood Name & Year & Notes \\
\hline 1 & Breasted & Marchant & indian cinnabar & 60 & Resin \\
\hline 2 & Breasted & Dioscorides & kinnabar & 90 & Resin \\
\hline 3 & Abu Hanifa & Al-sulaik & edah & 605 & Resin \\
\hline 4 & Ibn Manzur & Al-asmai & andam & 800 & Resin \\
\hline 5 & Ibn Manzur & Al-asmai & dum al-akhawin & 800 & Resin \\
\hline 6 & Ibn Sallam & & shian & 838 & Resin \\
\hline 7 & Ibn Sallam & & baqam & 838 & Resin \\
\hline 8 & Abu Hanifa & & shian & 869 & Tree \\
\hline 9 & Al-hamadani & & katir & 941 & Resin \\
\hline 10 & Ibn Manzur & Ibn Barii & al-huraifah & 1165 & Tree \\
\hline 11 & Ibn Al-baitar & & dum al-tinnin & 1248 & Resin \\
\hline 12 & Ibn Al-baitar & & dum al-thuban & 1248 & Resin \\
\hline 13 & Al-Firuzabadi & & dum al-akhawin & 1410 & Tree /Resin \\
\hline 14 & Al-Firuzabadi & & edah & 1410 & Tree/ Resin \\
\hline 15 & Al-Firuzabadi & & andam & 1410 & Tree/ Resin \\
\hline 16 & Wellsted & & dum khoheil & 1835 & Resin \\
\hline 17 & Wellsted & & dragon's blood & 1835 & Tree /Resin \\
\hline 18 & Wellsted & & moselle & 1835 & Resin \\
\hline 19 & Balfour & B.C.S & kharya & 1835 & Tree \\
\hline 20 & Breasted & Bent & blood of two brothers & 1893 & Resin \\
\hline 21 & Forbes & & arhieb & 1899 & Tree \\
\hline
\end{tabular}

Depending on the amount of sources for each time, frequency of names can be limited (e.g., few $1^{\text {st }}$ century AD sources). Most common are occurrences of edah, dum al-akhawin and dragon's blood, medium frequency words such as cinnabar, andam and katir, other names are in low frequency. Most of the names referred to the resin and few referred to the tree (shian, al-huraifah and kharya). The two names for the resin appearing in the first period (Fig. 3) were treated as one name because they came from the same origin "cinnabar". Four common names for the dragon's blood tree appear, "dum alakhawin", "edah", "al-huraifah" and "shian", besides the English name "Dragon's Blood Tree" of course.

Table 2. Dragon's blood names (resin/tree) frequency from 1st century AD - 2000 AD 


\begin{tabular}{|c|c|c|c|c|c|}
\hline \multirow[t]{2}{*}{ No. } & \multirow[t]{2}{*}{ Name } & \multicolumn{3}{|c|}{ Frequency } & \multirow[t]{2}{*}{ Authors } \\
\hline & & $\mathrm{R}$ & $\mathrm{T}$ & $T / R$ & \\
\hline 1 & Cinnabar & 3 & & & {$[51,71]$} \\
\hline 2 & edah & 9 & 1 & 1 & {$[53-58,72-77]$} \\
\hline 3 & andam & 5 & 1 & 1 & {$[53,55-57,74,78,79]$} \\
\hline 4 & dum al-akhawin & 19 & 2 & 1 & {$[53,55-57,72-86]$} \\
\hline 5 & shian & 7 & 2 & & {$[53,57,73-78,86]$} \\
\hline 6 & baqam & 1 & & & [53] \\
\hline 7 & katir & 4 & 1 & & {$[57,60,72,75,83]$} \\
\hline 8 & al-huraifah & & 1 & & {$\left[{ }^{55}\right]$} \\
\hline 9 & dum al-tinnin & 1 & 1 & & {$[57,78]$} \\
\hline 10 & dum al-thuaban & 3 & 1 & & {$[57,74,77,78]$} \\
\hline 11 & dum khoheil & 1 & & & [58] \\
\hline 12 & dragon's blood & 4 & 2 & 2 & {$[49,51,58,59,71]$} \\
\hline 13 & moselle & 1 & & & {$\left[{ }^{58}\right]$} \\
\hline 14 & kharya & & 1 & & {$\left[{ }^{58}\right]$} \\
\hline 15 & blood of two brothers & & & & {$\left[{ }^{51}\right]$} \\
\hline 16 & arhieb & & 1 & & {$\left[{ }^{49}\right]$} \\
\hline 17 & dum al-gazelle & & 1 & & {$\left[{ }^{57}\right]$} \\
\hline
\end{tabular}

The contemporary names (Table 3) are written according to where they occur in the references; names from Yemen, Saudi Arabia and Sudan were written in simplified English by the author. The names represent four species of Dracaena distributed in the Arab World, and present five languages (Socotri, Arabic, Hadandawa, Somali and Amazigh). Al the names in the table are for dragon's blood tree and the names of the resin "emsello" and "iydah" are added from Socotri. The word "dum al-akhawin" is used as a name for the tree and for the resin.

Table 3. Contemporary Arabic names of dragon's blood (tree/resin) in Arabic [39,62-64,87] 


\begin{tabular}{|c|c|c|c|c|c|c|}
\hline Area (D. species) & Dragon's & lood nan & s (tree/resir & & & \\
\hline $\begin{array}{l}\text { Socotra }(D . \\
\text { cinnabani) }\end{array}$ & a'arhiyib & iydiha* & emzoloh* & ahrieb & $\begin{array}{l}\text { dum al- } \\
\text { akhawin }\end{array}$ & \\
\hline $\begin{array}{l}\text { Yemen }(D . \\
\text { serrulata) }\end{array}$ & airob & kasar & kasl & arrab & khwas & $\begin{array}{l}\text { faliqat al- } \\
\text { gawz }\end{array}$ \\
\hline $\begin{array}{l}\text { Saudia }(D . \\
\text { serrulata) }\end{array}$ & arab & khazm & khazami & arrab & khaws & azaf \\
\hline $\begin{array}{l}\text { Oman }(D . \\
\text { serrulata) }\end{array}$ & areeb & & & ariab & & ayrob \\
\hline Sudan (D. ombet) & embet & emet & $\begin{array}{l}\text { ras al- } \\
\text { shitan }\end{array}$ & $\begin{array}{l}\text { shagart al- } \\
\text { Tinnin }\end{array}$ & & \\
\hline $\begin{array}{l}\text { Somalia }(D . \\
\text { ombet) }\end{array}$ & dinaw & mooli & & & & \\
\hline $\begin{array}{l}\text { Morocco }(D . \\
\text { draco) }\end{array}$ & ajgal & & & & & \\
\hline
\end{tabular}

* Dragon's blood resin

\section{Toponyms}

A total of 301 toponyms were recorded from the four study areas in Socotra Island (Table 4), which characterize how the Socotri people view their landscape. Toponyms were clustered in six broad categories based on their meaning:

- Animal: place name referring to animals such as livestock, birds, other

- Human; place names referring to human body parts, names, feeling, interaction, tools

- NA: place name with unknown meaning

- Plants; place names referring to plant species, density

- Terrain; place names referring to the shape and color of the landscape

- Water: place names referring to water such as rain, streams

Table 4. Distribution of the toponyms among categories and areas 


\begin{tabular}{|llllll|}
\hline Category/Area & Hagher & Ma'ala & Momi & Qataria & Total \\
\hline Animal & 7 & 8 & 6 & 5 & 26 \\
\hline Human & 26 & 15 & 17 & 15 & 73 \\
\hline NA & 9 & 7 & 10 & 6 & 32 \\
\hline Plant & 17 & 8 & 6 & 10 & 41 \\
\hline Terrain & 43 & 21 & 24 & 25 & 113 \\
Water & 7 & 0 & 6 & 3 & 22 \\
\hline Total & 109 & 59 & 69 & 64 & 301 \\
\hline
\end{tabular}

Most toponyms were recorded from the Hagher, the lowest number recorded from Ma'ala as this was through indirect communication.

It is clearly visible (Fig. 4), the most represented toponyms were related to terrain (37.5\%). People describe the topography of the land such as mountain, hill, flat and rock but also describe the general view of those areas such as open, narrow, protected, high and low, they describe also the soil and color of the land. Terrain toponyms are followed by names referring to Human characters and activities (24.3\%). Interestingly, most of these names referred to human activities such as playing, jumping, relaxing or giving and that can be related to a once frequent activity in the place, yet they also use feeling such as hunger and afraid, parts of the body like ears, neck and teeth if they resembled the topography by human parts. There are no naming places after people except two names for the tribes. Plant names represent $13.6 \%$, varying between $8.7 \%$ and $15.6 \%$ among study areas (Fig. 5). These three categories have a higher percentage within all study areas (Fig. 5). Toponyms related to animals and water have a lower percentage of $9 \%$ and $6.9 \%$ respectively, and there are names of unknown meaning $(10.6 \%)$.

Given the importance of plants for people in Socotra, it is not surprising that the names referred to plants come in the third position. Based on further analysis we divided the plant names into five subcategories (Table 5) based on their meaning;

- Unidentified: place names referring to the unidentified plant species

- Identified: place names referring to the identified plant species such as the Socotri word "Tayf" for Aloe

- General: place names referring to the word "plant" without any specification

- Density: place names referring to the plant density

- Grass: place names referring to grassland

Table 5. The frequency of place names in individual sub-categories of the phytotoponyms 


\begin{tabular}{|llllll|}
\hline Sub-category & Unidentified & Identified & General & Density & Grass \\
\hline Number & 5 & 22 & 6 & 6 & 2 \\
\hline Percentage (\%) & 12.2 & 53.7 & 14.6 & 14.6 & 4.9 \\
\hline
\end{tabular}

We found six records of phytotoponyms related to $D$. cinnabari, which represent $2 \%$ from all toponyms recorded, $14.6 \%$ from the phytotoponyms and $27.3 \%$ from the subcategory of phytotoponyms referring to identified plant species (Figs 6 and 7).

\section{Reconstruction of Dragon's blood tree distribution}

Among the six phytotoponyms referring to Dracaena (Fig. 7), one is located in the far end of Mala'a Mountains and two in the eastern edge of Momi plateau, far from the currently known $D$. cinnabari distribution. The other toponyms include three localities in Qataria where few remaining trees are known (Madera et al. 2019) and one in the Hagher, at the border of the current distribution of $D$. cinnabari. People in those areas have been interviewed individually, within group discussion and communication and the result is presented in the map (Fig. 8). People from Hagher speak about possible sites for $D$. cinnabari close to the areas of current distribution and people in Qataria and Momi speak about the possible sites for $D$. cinnabari in the cliffs towards the sea, however we could not confirm this during the study visit. During the fieldwork we recorded new sites with D. cinnabari (Fig. 8) where the trees have been observed. Both possible and new sites need further research.

\section{Discussion}

\section{Tracking dragon's blood tree phytotoponyms}

\section{Names through history}

According to the estimates based on genetic research, Socotra was inhabited ca. 6,000 years BP [ $\left.{ }^{88}\right]$. From the old manuscripts, cinnabar, derived from ancient Greek name for red mineral (mercury sulfide $\mathrm{HgS}$ ) and adapted as the scientific name for Socotra dragon's blood tree (Dracaena cinnabari), has no relation to Arabic current or historical names only perhaps by color. Arabic literature $\left[{ }^{53,55,80,82}\right]$ use dum al-akhwin as a common Arabic name for dragon's blood resin and sometimes for the tree without specification of the sources and sometimes for the resin brought from Socotra and this name continued to be used from the past until today. "Edah" is the only local Socotri name that appears significantly in Arabic literature [ $\left.{ }^{54,83}\right]$ especially for the resin of dragon's blood tree due to its famous use in medicine. Other Arabic old names for dragon's blood such as "andam" [ $\left.{ }^{78,79}\right]$, "dum al-thuban" $\left[{ }^{78}\right]$ and "shian" [ $\left.{ }^{73}\right]$ is used for other products for example "andam" used for logwood. "Dum al-tinnin" $\left[{ }^{78}\right]$ is the Arabic translation of dragon's blood and "katir" is the general name for drops. The first record for the local name 
of dragon's blood tree was in 1899 by Forbes (1903) [49] but edah and emsello ("moselle") have been mentioned also by Wellsted (1835) [ $\left.{ }^{58}\right]$. Cabo González and Bustamante Costa (2001) $\left[{ }^{89}\right]$ suggested that there is a weakness in dictionaries and confusion of terminology related to dragon's blood names and give an example of "andam" and "baqam", however andam with its red color can bring some confusion but baqam before $1500 \mathrm{AD}$ rarely mentioned in Arabic literature, in my review just once by lbn Manzur (1290) [ [5] from their review "shian" is a popular name for dragon's blood in Morocco which comes from Persian origin, however, the translation of dragon's blood to Persian is "khun-siawshan" which appears in 1205 by Abi Umran [ $\left.{ }^{75}\right]$, who divided the names by area; Arabic "dum al-akhawin and edah", Morocco "shian" and Persian "khun-siawshan". In their review, three other names of dragon's blood appear "Itr mansham", "Hagun" and "Tabdigha" referenced to Abu al-khair (ca 1200) $\left.{ }^{74}\right]$ and according to them, "Tabdiga" is from Amazigh language.

There is no sign of loss of cultural knowledge as a consequence of Arabic intervention. Only one name appears from Arabic (name of the plant) and that could be from an individual prospective or newly named, but there are still names that can't be explained by local people and that show their ancient roots. Although a large part of Socotra is uninhabited intensively by people - around 100 thousand inhabitants in $3,625 \mathrm{~km}^{2}$ - and many spaces have no urbanization. The human interaction is very clear by giving names for each patch of land (personal observation) and the huge walls "eggehon" dominated the landscape especially in the higher altitudes; this confirms that Socotri people have strong knowledge, understanding, interactions and connection with places, and has been claimed as circumstantial evidence that the wall system on Socotra might be a sign of past historical intensive farming activities for incense, dragon's blood, or aloes $\left[{ }^{90}\right]$.

\section{Current Names}

There are four dragon's blood trees in the Arabic speaking regions, $D$. cinnabari in Socotra, $D$. serrulata in Yemen, Oman and Saudi Arabia, D. ombet in Saudi Arabia, Sudan, Egypt, Ethiopia and Somalia, and D. draco subsp. ajgal in Morroco. We have seven groups of names according to the area (Table 2). Ahrieb with its different form of writing and pronunciation is the common local name for all dragon's blood tree species in Arabic (Yemen, Socotra, Oman and Saudia Arabia) [39,62-64,87]. Although different names appear such as "Ajgal" in Morocco in the Amazigh language and "Embet" in Sudan in the Hadandawa language and "Mooli" in Somalia in the Somali language. In Socotra, there is only one local name for the dragon's blood tree which is "ahrieb"; other names "emsello" for the pure product or "edah" is the mixed product with tree bark [ $39,62,64]$ and due to the difference in dialect, people of western Socotra call it "ahrieb" Socotra. Other current Arabic local names linked the leaves and its similarity with palm leaves such as "khwas" and "khazm", the same is used for the leaves of dragon's blood tree in Socotra "sa'af" which are also used for the palm leaves. The names in Morocco, Sudan and Somalia aren't linked to Arabic, "ajgal" and "ombet" are in local languages and have been used for the scientific name. 


\section{Toponym}

The use of geographical/ecological-based toponyms stands as a potentially useful tool for the aiding the reconstruction of historical changes. Toponyms have rarely been used as a biogeographic indicator of species or vegetation type occurrences [35]. Analyzing the toponyms (Fig. 5) shows a high frequency of names referring to terrain. Zeini et al. (2018) [ ${ }^{91}$ ] study in Sinai (Egypt) classified $69.9 \%$ of their recorded place names as referring to landforms followed by names that referred to water. Human place names are typically metaphorical, alluding to a resemblance between some physical feature of a site and shape of the organ after which it is named [ $\left.{ }^{13}\right]$. In Socotra, the human place names describe where things happen, places where people harvest, gather the goats, collect water or play and they have a general name for a whole area or landmark (like a mountain). Plotting of the distribution of plant names in Socotra is another way to appreciate and display the ecological niche and knowledge.

Plant names (phytotoponyms), which are our focus in this research, come in the third position with a frequency of $13.6 \%$. Most of the phytotoponyms that are for general names or uses, while $53.7 \%$ of all phytotoponyms could be identified to scientific names and $12.2 \%$ we couldn't identify scientific names (Table 4). This shows a strong connection between the people and the plants. The identified plants are important for food, fodder and fire wood (Phoenix, Tamarix, Punica), famous with their products such as (Dracaena and Aloe) $\left.{ }^{39}\right]$. Similarly, Shi et al. (2015) [28] mentioned that plant names often used in daily life appear frequently in phytotoponyms. In Socotra, trees and large shrubs easily distinguished in the landscape such as Commiphora and Maerua, represent land marks (Wolf 1998: Camarda 2005 cited by Pinna et al. 2017) $\left[{ }^{37}\right]$ and these categories give a good sign for orientation and recognizing the landscape. Water was in the last position, with 5.3\% names related to water existence or its amount. Comparing within areas we found out that eastern sites have more place names related to water than western site and that looks logically with a higher amount of water in eastern Socotra than in the western areas $\left.{ }^{42}\right]$. Names related to cows and goats represent the main animal toponyms because they are the main livestock on the island. All areas have a similar percentage of names referring to animals that can be explained by the fact that grazing is common in the selected areas and on the island in general. Names with unknown meaning could be linked to ancient language as suggested also by Wagner (19601964) cited by Pinna et al. (2017) $\left[{ }^{37}\right]$.

\section{Potential implications for past dragon's blood tree distribution}

Dragon's blood tree name appears 6 times which represent $14.6 \%$ of the phytotoponyms, four occurrences in western Socotra with two different variants and two in eastern Socotra with also two different variants. Pérez (2003) [92] also noted three different variants of the phytotoponym "drago" in Canary Islands, exploring the local dialects. All the names in the west of the island are not single name but linked to other words, $D$. cinnabari pool, $D$. cinnabari sign, $D$. cinnabari place and $D$. cinnabari stand. 
The six names included two names associated with existing $D$. cinnabari tree, one name associated with a place close to $D$. cinnabari trees and there having been trees before, one name associated to a place close to $D$. cinnabari tree but nobody remembers that there was tree before, one name with no tree near, but according to local people it could exist and one name with no trees and historically nobody know of trees existence on the area.

Half of the $D$. cinnabari place names occurs in Qataria, the area with the few limited isolated trees. Qataria is the farthest western site of current $D$. cinnabari distribution on the island and the place names of $D$. cinnabari are near and around the remnant $D$. cinnabari trees. According to the local people in the area, there is a possibility of small dragon's blood trees in the cliffs towards the sea, which provides an opportunity for discovering new Dracaena sites in the area. This area is the western end of the ridge stretching from the central Hagher Mts. and it indicates that the entire ridge could be likely covered by Dracaena forests in the past, even though Attorre et al. (2007) $\left.{ }^{70}\right]$ did not assign most of this area to the model of potential Dracaena cinnabari distribution. The second area in Momi on the eastern side of the island, there is a $D$. cinnabari place name but also according to the local community there is also possibility of $D$. cinnabari trees on the cliffs towards the sea. In fact, this area is not far from recent Dracaena population and was included in the potential Dracaena occurrence made by Attorre et al. (2007) [70].

The third place is Ma'ala (in the west), where is a D. cinnabari place name but no more information and there was no opportunity for visiting the site. This finding is the most important because is the furthest from recent $D$. cinnabari distribution. In entire western part of Socotra, there is no one current record of Dracaena occurrence beyond Qataria $\left[{ }^{47}\right]$ and this toponym would also confirm the model of potential Dracaena occurrence in the Ma'ala's Highland published by Attorre et al. (2007) [ $\left.{ }^{70}\right]$.

The last $D$. cinnabari place name in the Hagher is close to $D$. cinnabari population but the name is for a place without $D$. cinnabari trees and they don't know presence of tree in the place, another $D$. cinnabari place name was also recorded from Hagher towards To'ahor's campsite-outside or study area (communication with local people).

In all investigated areas, there are still preserved some plant species accompanying dragon's blood tree woodlands as Boswellia ameero, B. elongata, Buxanthus pedicellatus, Commiphora planifrons, Euphorbia socotrana or Euryops arabicus [ $\left.{ }^{93-99}\right]$. Occurrence of these plants can serve as an indirect indicators of previous $D$. cinnabari distribution according to the plant communities.

Generally, the $D$. cinnabari place names seem to be associated with the current and potential distribution. The similar result was obtained by Pérez (2003) [92] for Dracaena draco on Gran Canaria, in his map, there are 42 phytotoponyms; 2 names associated with existing $D$. draco occurrence, others are close to the current distribution of individual trees or in area of potential distribution. The population decline of Dracaena draco is much larger than thus documented on Socotra island by many authors [43,70,100-103]. Overgrazing destroying the natural regeneration $\left[{ }^{104}\right]$ and very slow growth of recruitment $\left[{ }^{105}\right]$ do not 
allow the trees to escape from browsing zone $\left[{ }^{47,48,106}\right]$. Therefore, these are known as the main reasons of population decline. The loss of each tree leads to the decrease in biodiversity, dragon's blood trees are important nurse trees $\left[{ }^{46}\right]$ and habitats for the animals [ $\left.{ }^{107,108}\right]$ also. The loss of dragon's blood trees may also affect the hydrological cycle as these plants capture horizontal precipitation [109].

\section{Conclusion}

In Socotra, luckily the landscape still has its original characteristic with relatively little human interventions $\left[{ }^{69}\right]$, although the natural and human landscape are rapidly changing $\left[{ }^{110}\right]$. Ethnobotanical knowledge has been preserved within its unique language $\left[{ }^{39}\right]$. We can summarize our conclusions in seven main points:

1. Dracaena cinnabari toponyms exist in Socotra and seem related to areas where currently no trees are present, yet they were historically a feature of the place; this could support the argument that the distribution of Dracaena was larger in the past $\left[{ }^{70}\right]$.

2. The cinnabari trees could be distributed to the whole medium to higher altitude areas on the Island, potentially from the west in Ma'ala to the east in Momi, before humans inhabited the Island.

3. Currently the Arabic common name for dragon's blood resin is "dum al-akhawin", for the tree is "ahrieb" and can be generalized.

4. The local name that appeared in history for the main product is "edah" (Mixed-cooked dragon's blood) and this can be a sign that "edah" was the main product exported from Socotra.

5. There could be potentially new areas for finding cinnabari trees especially in cliffs areas towards the sea in Qataria and Momi, also the northeastern slopes of Hagher towards Momi plateau in the east and Noged plain to the North.

6. This result can be an important part of conservation efforts and those areas with cinnabari toponyms could be potential areas for future reforestation of this species, where the ecological conditions allow.

7. The study has stressed the need for documenting place names and knowledge related as part of preserving the cultural heritage related to plants of Socotra Archipelago and the importance of using this knowledge for sustainable resource management. This study is just a first step for further use of toponyms and can be repeated for other important species or historical land use.

\section{Declarations}

\section{Ethics approval and consent to participate}

Not applicable

\section{Consent for publication}


Not applicable

\section{Availability of data and materials}

All data generated or analysed during this study are included in this published article [and its supplementary information files].

\section{Competing interests}

The author declare that he has no competing interests

\section{Funding}

No funding, the research is part of my PhD study in Mendel University in Brno, Czech Republic

\section{Authors' contributions}

One Author

\section{Acknowledgements}

Special thanks to my supervisor Prof. Petr Maděra for his wholehearted scientific guidance, encouragement, and support during the design, data analysis, and write-up phases. I am also grateful for Dr. Kay Van Damme for his valuable comments and encouragement. Thanks to the people of Socotra for their kindness, generosity and support. Special thanks to Dr. Sa'ad Amer, Dr. Nooh Al-Alimi, Ing. Ahmed Alrumaili and Ing. Ahmed Al-terbhi for their great support, advice reviewing and commenting on meaning of Socotri's names. My great thanks is extended to all friends who support me during this work.

\section{Authors' information}

The Author have been living and working in Socotra Island for more than 20 years, the author work in natural conservation especially with local communities.

\section{References}

(1) Gerique A. An Introduction to Ethnoecology and Ethnobotany: Theory and Methods. Integrative Assessment and Planning Methods for Sustainable Agroforestry in Humid and Semiarid Regions. Advanced Scientific Training (ed.), 20p. Loja, Ecuador. 2006.

(2) De Carvalho LMM. The Symbolic Uses of Plants. In Ethnobiology (eds E.N. Anderson, D. Pearsall, E. Hunn and N. Turner). 2011. https://doi.org/10.1002/9781118015872.ch21.

(3) Studley J. Dominant Knowledge Systems and Local Knowledge. In Mountain Forum: A global network for mountain communities, environment and sustainable development. 1998. 
(4) Harshberger JW. The Purposes of Ethno-Botany. Botanical gazette. 1896.

(5) Horák M, Růžičková G, Kocourková B, Sapáková E, Kavenská V, Cruz L, Škrabáková L, Tournon J, Alpala M, Forero Pinto L, Rosero A, Castro N, Beltran G, Halbich M, Ortega F, Sobiecki J, Amirova E. A Reader in Ethnobotany and Phytotherapy, Editor: Miroslav Horák.; Mendel University in Brno. 2014.

(6) Naftali N. Toponymy: The Lore, Laws and Language of Geographical Names. New York. 2000.

(7) Gruzdeva E, Temina M. Nivkh Toponyms in the Amur-Sakhalin Region of the Russian Far East. Altai hakpo. 2020.

(8) Rose-Redwood R, Alderman D, Azaryahu M. Geographies of Toponymic Inscription: New Directions in Critical Place-Name Studies. Progress in Human Geography. 2010.

(9) Qian S, Kang M, Wang M. An Analysis of Spatial Patterns of Toponyms in Guangdong, China. J. Cult. Geogr 2016.

(10) Zhong A, Wu Y, Nie K, Kang M. Using Local Toponyms to Reconstruct the Historical River Networks in Hubei Province, China. ISPRS International Journal of Geo-Information. 2020.

(11) Cunningham AB. Applied Ethnobotany: People, Wild Plant Use and Conservation; Earthscan. 2001.

(12) Berkes F. Traditional Ecological Knowledge in Perspective. In: Inglis, J. T. (Ed) Traditional Ecological Knowledge: Concepts and Cases; International Development Research Centre: Canada; 1993.

(13) Hunn E. Columbia Plateau Indian Place Names: What Can They Teach Us? Journal of Linguistic Anthropology. 1996.

(14) Ford RE. Toponymic Generics, Environment, and Culture History in Pre-Independence Belize. Names. 1991.

(15) Zhao F, Fu Y, Luan G, Zhang S, Cai J, Ding J, Qian J, Xie Z. Spatial-Temporal Characteristic Analysis of Ethnic Toponyms Based on Spatial Information Entropy at the Rural Level in Northeast China. Entropy. 2020 .

(16) Morphy F, Morphy H, Faulkner P, Barber M. Toponyms from 3000 Years Ago? Implications for the History and Structure of the Yolnu Social Formation in North-east Arnhem Land. Archaeology in Oceania. 2020. https://doi.org/DOI:10.1002/arco.5213.

(17) Sousa A, García-Murillo P. Can Place Names Be Used as Indicators of Landscape Changes? Application to the Doñana Natural Park (Spain). Landscape Ecology. 2001. https://doi.org/10.1023/A:1017585101389.

(18) Sweeney S, Jurek M, Bendnar M. Using Place Names to Interpret Former Floodplain Connectivity in the Morava River, Czech Republic. Landscape Ecology. 2007. https://doi.org/10.1007/s10980-007-9085- 
(19) Sousa A, García-Murillo P. Sahin S, Morales J, García-Barrón L. Wetland Place Names as Indicators of Manifestations of Recent Climate Change in SW Spain (Doñana Natural Park). Climatic Change. 2010. https://doi.org/10.1007/s10584-009-9794-9.

(20) Frajer J, Fiedor D. Discovering Extinct Water Bodies in the Landscape of Central Europe Using Toponymic GIS. Moravian Geographical Reports, 2018.

(21) Henshaw A. Pausing along the Journey: Learning Landscapes, Environmental Change, and Toponymy amongst the Sikusilarmiut. Arct. Anthropol. 2006.

(22) Westing AH. Cultural and Spiritual Values of Biodiversity. Environment. 2000.

(23) Tattoni C. Nomen Omen. Toponyms Predict Recolonization and Extinction Patterns for Large Carnivores. Nature Conservation. 2019. https://doi.org/10.3897/natureconservation.37.38279.

(24) Aybes C, Yalden DW. Place-Name Evidence for the Former Distribution and Status of Wolves and Beavers in Britain. Mammal Review. 1995. https://doi.org/10.1111/j.1365-2907.1995.tb00444.x.

(25) Boisseau S, Yalden DW. The Former Status of the Crane Grus grus in Britain. The Ibis. 1998. https://doi.org/10.1111/j.1474-919X.1998.tb04610.x.

(26) Hough C. Deer in Sussex Place-Names. The Antiquaries Journal. 2008. https://doi.org/10.1017/S0003581500001347.

(27) Calvo-Iglesias MS, DÍaz-Varela R.A, MÉndez-MartÍnez G, Fra-Paleo U. Using Place Names for Mapping the Distribution of Vanishing Historical Landscape Features: The Agras Field System in Northwest Spain. Landscape Research. 2011. https://doi.org/10.1080/01426397.2011.604716.

(28) Shi G, Ren F, Du Q, Gao N. Phytotoponyms, Geographical Features and Vegetation Coverage in Western Hubei, China. Entropy. 2015.

(29) Gruezo WS. Of Philippine Plants and Places: An Ethnobotanical Memoir. Asia Life Sciences. 1999.

(30) Fagúndez J, Izco J. Diversity Patterns of Plant Place Names Reveal Connections with Environmental and Social Factors. Applied Geography. 2016.

(31) Čargonja H, Đaković B, Alegro A. Plants and Geographical Names in Croatia. Coll. Anthr. 2008.

(32) Bacchetta G, et al. A Survey of the Botanical Place Names of the Iglesiente Area (South West Sardinia). Botanica Lithuanica. 2007.

(33) Conedra M, Vassere S, Neff C, Meurer M, Krebs P. Using Toponymy to Reconstruct Past Land Use: A Case Study of 'Brüsáda' (Burn) in Southern Switzerland. Journal of Historical Geography. 2007. 
(34) Fei S. The Geography of American Tree Species and Associated Place Names. Journal of Forestry. 2007.

(35) Pagán-Jiménez JR, Lazcano-Lara JC. Toponymic Data Helps to Reveal the Occurrence of Previously Unknown Populations of Wild Zamia pumila L. on Volcanic Substrates in South-Central Puerto Rico. Ethnobiology Letters. 2013.

(36) Fagúndez J, Izco J. Spatial Analysis of Heath Toponymy in Relation to Present-Day Heathland Distribution. International Journal of Geographical Information Science. 2015.

(37) Pinna C, Carta L, Deiana V, Camarda I. Phytotoponyms of Arbutus unedo L. and Their Distribution in Sardinia (Italy). PloS one. 2017. 12(7), p.e0181174.

(38) Barau AS, Abdulhamid A. Using Toponyms to Trace and Document Depletion of Indigenous Trees in a Dryland African City. Northwest: A Book of Readings. 2018.

(39) Miller AG, Morris M. Ethnoflora of the Soqotra Archipelago.; Royal Botanic Garden Edinburgh; 2004.

(40) Fleitmann D, Burns SJ, Mangini A, Mudelsee M, Kramers J, Villa I, Neff U, Al-Subbary AA, Buettner A, Hippler D, Matter A. Holocene ITCZ and Indian Monsoon Dynamics Recorded in Stalagmites from Oman and Yemen (Socotra). Quaternary Science Reviews 26, no. 1-2: 170-188. 2007.

(41) Van Rampelbergh M, Fleitmann D, Verheyden S, Cheng H, Edwards L, De Geest P, De Vleeschouwer D, Burns SJ, Matter A, Claeys P, Keppens E. Mid-to Late Holocene Indian Ocean Monsoon Variability Recorded in Four Speleothems from Socotra Island, Yemen. Quaternary Science Reviews. 2013.

(42) Van Damme K, Vahalík P, Ketelaar R, Jeziorski P, Bouwman J, Morris M, Suleiman AS, Dumont HJ. Dragonflies of Dragon's Blood Island: Atlas of the Odonata of the Socotra Archipelago (Yemen). Rendiconti Lincei. Scienze Fisiche e Naturali. 2020.

(43) Habrova H, Cermak Z, Pavlis J. Dragon's Blood Tree-Threatened by Over-maturity, Not by Extinction: Dynamics of a Dracaena cinnabari Woodland in the Mountains of Soqotra. Biological conservation. 2009, $142(4), 772-778$.

(44) Lvončík S, Vahalík P, Bongers F, Peijenburg J, Hušková K, Van Rensburg J, Hamdiah S, Maděra P. Development of Boswellia elongata Balf. F., Population in Homhil Protected Area, Soqotra. Rendiconti Lincei. 2020. https://doi.org/10.1007/s12210-020-00936-4.

(45) Rezende M, Riccardi T, Malatesta L, Attorre F, Van Damme K. Land Productivity Dynamics in Socotra Island (Yemen). Rendiconti Lincei. Scienze Fisiche e Naturali. 2020. https://doi.org/10.1007/s12210-02000928-4.

(46) Rejžek M, Svátek M, Šebesta J, Adolt R, Maděra P, Matula R. Loss of a Single Tree Species Will Lead to an Overall Decline in Plant Diversity: Effect of Dracaena cinnabari Balf. f. on the Vegetation of Socotra 
Island. Biological Conservation. 2016, 196, 165-172.

(47) Maděra P, Volařík D, Patočka Z, Kalivodová H, Divín J, Rejžek M, Vybíral J, Lvončík S, Jeník D, Hanáček P. Sustainable Land Use Management Needed to Conserve the Dragon's Blood Tree of Socotra Island, a Vulnerable Endemic Umbrella Species. Sustainability. 2019, 11 (13), 3557.

(48) Maděra P, Forrest A, Hanáček P, Vahalík P, Gebauer R, Plichta R, Jupa R, Rensburg JJV, Morris M, Nadezhdina N, Vaníčková L, Jura-Morawiec J, Wiland-Szymańska J, Kalivodová H, Lengálová K, Rejžek M, Habrová H. What We Know and What We Do Not Know About Dragon Trees? Forests, 2020, 11 (2), 236. https://doi.org/10.3390/f11020236.

(49) Forbes LLD. Narrative of the Journey. In The natural history of Sokotra and Abd-el-Kuri; Pp. xv-xlvi. In: FORBES H. O. (ed.); 1903.

(50) Elie SD. Soqotra: South Arabia's Strategic Gateway and Symbolic Playground. British Journal of Middle Eastern Studies. 2006, 33 (2), 131-160.

(51) Breasted JH. The Periplus of the Erythraean Sea: Travel and Trade in the Indian Ocean by a Merchant of the First Century, Translated from the Greek and annotated by Wilfred h. Schoff, AM, Secretary of the Commercial Museum, Green, and Company: Philadelphia. London; 1912.

(52) IBIDIS Press. DIOSCORIDES. DE MATERIA MEDICA; IBIDIS PRESS: PO Box 81169 Parkhurst Johannesburg South Africa 2120, 2000.

(53) Ibn Sallam, Abū खUbayd al-Qāsim. al-Gharīb al-mușannaf, Șafwān đAdnān Dāwūdī.; dar al-fayha'a: Beirut-Lebanon; 2005.

(54) Abu Hanifa ad-Dīnawarī (869). Book of Plants, Edited by Bernhard Lewin.; Franz Steiner Verlag: Wiesbaden, Germany; 1974.

(55) Ibn Manzur, Muhammad ibn Mukarram (1290). Lisān al-囚Arab; Dar Sader: Beirut, Lebanon; 1990.

(56) Al-Firuzabadi, Abū al-Ṭāhir Majīd al-Dīn (1410). Al-Qamus al-Muhit, suppervisedby: Muhammad Naim al-Irqsusi.; Mu`asasat al-Risalah: Beirut, Lebanon; 2005.

(57) Ahmed I. Bek. Mu'jam Asma’a Al-nbat; Al-Matba’a al-Amiriya-Cairo: Cairo, Egypt; 1926.

(58) Wellsted JR. Memoir on the Island of Socotra. The Journal of the Royal Geographical Society of London. 1835, 5, 129-229.

(59) Balfour IB. Botany of Socotra; Trans. Roy. Soc. Edinburgh; 1888; Vol. 31:1-446.

(60) Balfour IB. Botany of Socotra and Abd-Elkori. In Natural History of Socotra and Abd-elkori; Livepool Museem P.P. 598, 1903. p. 445-570. 
(61) Bent T, Bent M. Southern Arabia; Smith, Elder and Co: London; 1900.

(62) Al-Khulaidi AW. Flora of Yemen. The Sustainable Natural Resource Management Project (SNRMP II), EPA and UNDP; 2013.

(63) Al-Khulaidi AW, Al-Sagheer N, Darfaoui E, Al-Ameri SM. Trees of Al Baha Region and Surrounding Areas; FAO, Ministry of Environment, Water and Agriculture, Saudia arabia, 2016.

(64) Al-Okaishi A. Local Management System of Dragon's Blood Tree (Dracaena cinnabari Balf. f.) Resin in Firmihin Forest, Socotra Island, Yemen. Forests. 11 (389). https://doi.org/10.3390/f11040389.

(65) Cheung C, De Vantier L. Socotra-a Natural History of the Islands and Their People, In: Van Damme K (ed) Odessey books and guides. Airphoto International Ltd.; Hong Kong; 2006.

(66) UNESCO. Socotra Archipelago, Yemen. UNEP-WCMC, World Heritage List. 2008.

(67) Batelka J. Socotra Archipelago--a Lifeboat in the Sea of Changes: Advancement in Socotran Insect Biodiversity Survey. Acta Entomologica, Musei Natioalis Pragae. 2012.

(68) Testen D. The Loss of the Person-Marker" t-" in Jibbali and Socotri. Bulletin of the School of Oriental and African Studies, University of London, 1992.

(69) Van Damme K, Banfield L. Past and Present Human Impacts on the Biodiversity of Socotra Island (Yemen): Implications for Future Conservation. Zool Middle East. 2011.

(70) Attorre F, Francesconi F, Taleb N, Scholte P, Saed A, Alfo M, Bruno F. Will Dragon blood survive the next Period of Climate Change? Current and Future Potential Distribution of Dracaena cinnabari (Socotra, Yemen). Biological conservation. 2007, 138 (3-4), 430-439.

(71) Naumkin VV, Sedov AV. Monuments of Socotra. Topoi. Orient-Occident. 1993, 3(2), 569-623.

(72) Al-Hamadani, al-Ḥasan Ibn-Aḥmad (945). Sifat Jazirat al-Arab, Investigator: Muhammad bin Ali AlAkwa.; Maktabt al-Irshad: Yemen; 1990.

(73) Ibn al-Qatta, Ali ibn Jafar (1124). Abniyat al-asma wa-al-afal wa-al-masadir, Investigator: Prof. Ahmed Mohamed Abdel Dayem.; Dar al-Kutub wa-al-Wathaiq al-Qawmiyah, Markaz Tahqiq al-Turath: Egypt; 1999.

(74) Abu al-Khair al-Ishbily (ca: 1200). Kitāb 『Umdat al-țabīb fī ma冈rifat al-nabāt li-kull labīb, Investigator: Mohammed al-Arabi al-Khattabi.; Dar al-Gharb al-Islami: Beirut, Lebanon; 1995.

(75) Abi Umran Musá bin 囚Ubayd-Allâh “Maimonides,” (1204). Sharh asmā' al-邓uqqār, Investigator: Max Meyerhof (1874-1945). Maktabat al-Thaqafa al-Diniyya: Port said-Egypt; 2000. 
(76) Ibn al-Hasha (1250). Mufeed al-ulom wa mubeed al-humum, Investigator: Georges S. Colin; Ranaud H. J.; Mațbūđāt Ma囚had al-囚Ulūm al-囚Ulyā al-Maghribīyah, al-juz' 11: Morocco; 1941.

(77) Al-Ghassani al-rasoly (1297). Al-Mu囚tamad Fī al-Adwiyah al-Mufradah; Dar al-kotob al-Ilmiyah: Beirut, Lebanon; 2000.

(78) Ibn al-Baitar, Abd Allāh ibn Aḥmad (1248). Kitāb Al-Jāmi囚 Li-Mufradāt al-Adwiya Wa-I-Aghdhiya; Dar al-kotob al-Ilmiyah: Beirut, Lebanon; 1992.

(79) Al-Umari, Sahabudden ibn fadlullah (1349). Masālik al-Abșār fī Mamālik al-Amșār, Edited by: Kamil S. al-juburi and Mahdi al-Najm.; Dar al-kotob al-Ilmiyah: Lebanon; 2010.

(80) Al-Razi, Abū Bakr Muhammad ibn Zakariyyā. Kitāb al-Ḥāwī fī al-țibb, Invest; Mohammed. M. Ismail.; Dar al-kotob al-Ilmiyah; 2000.

(81) Ibn al-Gazar (979). Al-Etimad Fī al-Adwiyah al-Mufradah; Manuscript: Hagia Sophia Library: Turkey. https://www.alukah.net/library/0/89029/. Accessed 10 August 2020.

(82) Ibn Sina "Avicenna" (1020). Al-Qanun fi al-Tibb; Dar al-kotob al-IImiyah: Beirut, Lebanon; 1999.

(83) Al-Hamawi, Yāqūt ibn \Abd Allāh (1224). Mu’jam al-Buldan, Dar Sader.; Beirut, Lebanon; 1977.

(84) Ibn al-Nafis (1288). al-Mūjaz fī al-Tibb, Manuscript. https://www.wdl.org/ar/item/17147/. Accessed 29 January 2020.

(85) Al-antaki (1599). Tadhkirat Uli L-al-Bab Wa I-Jami Li-L-'Ajab al-'Ujab, copyied book from https://books-library.online/. Accessed 06 October 2020.

(86) Al-Ghassani al-Wazir (1610). Hadikat Al-Azhar Fi Mahyyat al-Ushb Wal-Aqqar, Annotated and commented by Al-Khattabi, M. A.; Dar al-Gharb al-Islami: Beirut, Lebanon; 1990.

(87) Serjeant RB. Plants of Dhofar, the Southern Region of Oman, Traditional, Economic and Medicinal Uses., By Anthony G. Miller and Miranda Morris, illustrated by Susanna Stuart-Smith with a foreword by Sultan Qaboos Bin Saif and preface by RE Schultes.; Office of the Adviser for Conservation of the Environment, Diwan of Royal Court, Sultanate of Oman. Journal of the Royal Asiatic Society. 1989.

(88) Černý V, Pereira L, Kujanová M, Vašíková A, Hájek M, Morris M, Mulligan CJ. Out of Arabia-the Settlement of Island Soqotra as Revealed by Mitochondrial and $\mathrm{Y}$ Chromosome Genetic Diversity. Am J Phys Anthropol. 2009. https://doi.org/10.1002/ajpa.20960.

(89) Cabo González AM, Bustamante Costa J. En Torno al Drago, Dracaena draco (L.): Notas de Fitonimia Árabe. Al-Andalus Magreb. 2001.

(90) Jansen van Rensburg J, Hopper K. Incense and Imagery: Mapping Agricultural and Water Management Systems on the Island of Socotra, Yemen. Proceedings of the Seminar for Arabian Studies, 
Archaeopress. 2017, 47, 129-138.

(91) Zeini NT, Abdel-Hamid AM, Soliman AS, Okasha AE. An Exploratory Study of Place-Names in Sinai Peninsula, Egypt: A Spatial Approach. Annals of GIS. 2018.

(92) Pérez RSA. Sobre La Presencia de Dracaena draco (L.) L. En Gran Canaria (Islas Canarias): Aportación Corólogica, Estado Actual y Significación Biogeográfica. Botanica Macaronésica. 2003.

(93) Buček A, Habrová H, Maděra P, Král K, Modrý M, Lacina J, Pavliš J. Application of the Czech Methodology of Biogeographical Landscape Differentiation in Geobiocoenological Concept - Examples from Cuba, Tasmania and Yemen. Journal of Landscape Ecology. 2015.

(94) De Sanctis M, Adeeb A, Farcomeni A, Patriarca C, Saeed A, Attorre F. Classification and Distribution Patterns of Plant Communities on Socotra Island, Yemen. Appl. Veg. Sci. 2013.

(95) Habrová H, Buček A. Overview of Biotope Types of Socotra Island. Journal of Landscape Ecology. $2013,6(3), 60-83$.

(96) Lvončík S, Maděra P, Volařík D, Habrová H, Vrškový B. First Proposal of Seed Regions for Frankincense Trees (Boswellia Spp.) at Socotra Island. Journal of Landscape Ecology. 2013.

(97) Maděra P, Kovář P, Vojta J, Volařík D, Úradníček L, Koblížek J, Jelínek P, Salašová A. Vegetation Succession along New Roads at Soqotra Island (Yemen): Effects of Invasive Plant Species and Utilization of Selected Native Plant Resistance against Disturbance. Journal of Landscape Ecology. 2013.

(98) Kürschner H, Hein P, Kilian N, Hubaishan MA. Diversity and Zonation of the Forests and Woodlands of the Mountains of Northern Socotra, Yemen. Englera. 2006.

(99) Habrová H. Geobiocoenological Differentiation as a Tool for Sustainable Land-Use of Socotra Island. Ekologia(Bratislava)/Ecology(Bratislava). 2004, 23, 47-57.

(100) Adolt R, Maděra P, Abraham J, Čupa P, Svátek M, Matula R, Šebesta J, Čermák M, Volařík D, Koutecký T. Field Survey of Dracaena cinnabari Populations in Firmihin, Socotra Island: Methodology and Preliminary Results. Journal of Landscape Ecology. 2013, 6 (3), 7-34.

(101) Adolt R, Habrova H, Madera P. Crown Age Estimation of a Monocotyledonous Tree Species Dracaena cinnabari Using Logistic Regression. Trees. 2012, 26 (4), 1287-1298.

(102) Hubálková I. Prediction of Dragon's Blood Tree (Dracaena cinnabari Balf.) Stand Sample Density on Soqotra Island. Journal of Landscape Ecology. 2011, 4 (2), 5-17.

(103) Adolt R, Pavlis J. Age Structure and Growth of Dracaena cinnabari Populations on Socotra. Trees. 2004, $18(1), 43-53$. 
(104) Habrová H, Pavliš J. Dynamic Response of Woody Vegetation on Fencing Protection in Semi-Arid Areas; Case Study: Pilot Exclosure on the Firmihin Plateau, Socotra Island. Saudi J Biol Sci. 2017. https://doi.org/10.1016/j.sjbs.2015.09.030.

(105) Maděra P, Habrová H, Šenfeldr M, Hubálková I, Lvončík J, Ehrenbergerová I, Roth M, Naděždina N, Němec P, Rosenthal J, et al. Growth Dynamics of Endemic Dracaena cinnabari of Socotra Island Suggest Essential Elements for a Conservation Strategy. Biologia. 2018, 74 (4), 339-349.

(106) Hubálková I, Maděra P, Volařík D. Growth Dynamics of Dracaena cinnabari under Controlled Conditions as the Most Effective Way to Protect Endangered Species. Saudi journal of biological sciences. 2017, 24 (7), 1445-1452.

(107) García C, Vasconcelos R. The Beauty and the Beast: Endemic Mutualistic Interactions Promote Community-Based Conservation on Socotra Island (Yemen). J Nat Conserv. 2017. https://doi.org/10.1016/j.jnc.2016.11.005.

(108) Fasola M, Razzetti E, Sindaco R, Ziliani U, Delle Monache D, Pellitteri-Rosa D, Vasconcelos R, Carranza S. Ecological Preferences of the Endemic Reptile Community of Socotra. Rendiconti Lincei. Scienze Fisiche e Naturali. 2020. https://doi.org/10.1007/s12210-020-00922-w.

(109) Kalivodová H, Culek M, Čermák M, Maděra P, Habrová H. Potential Importance of Socotra Dragon's Blood Tree Cloud Forests and Woodlands for Capturing Horizontal Precipitation. Rendiconti Lincei. 2020. https://doi.org/10.1007/s12210-020-00933-7.

(110) Attorre F, Van Damme K. Twenty Years of Biodiversity Research and Nature Conservation in the Socotra Archipelago (Yemen). Rendiconti Lincei. Scienze Fisiche e Naturali. 2020.

\section{Figures}



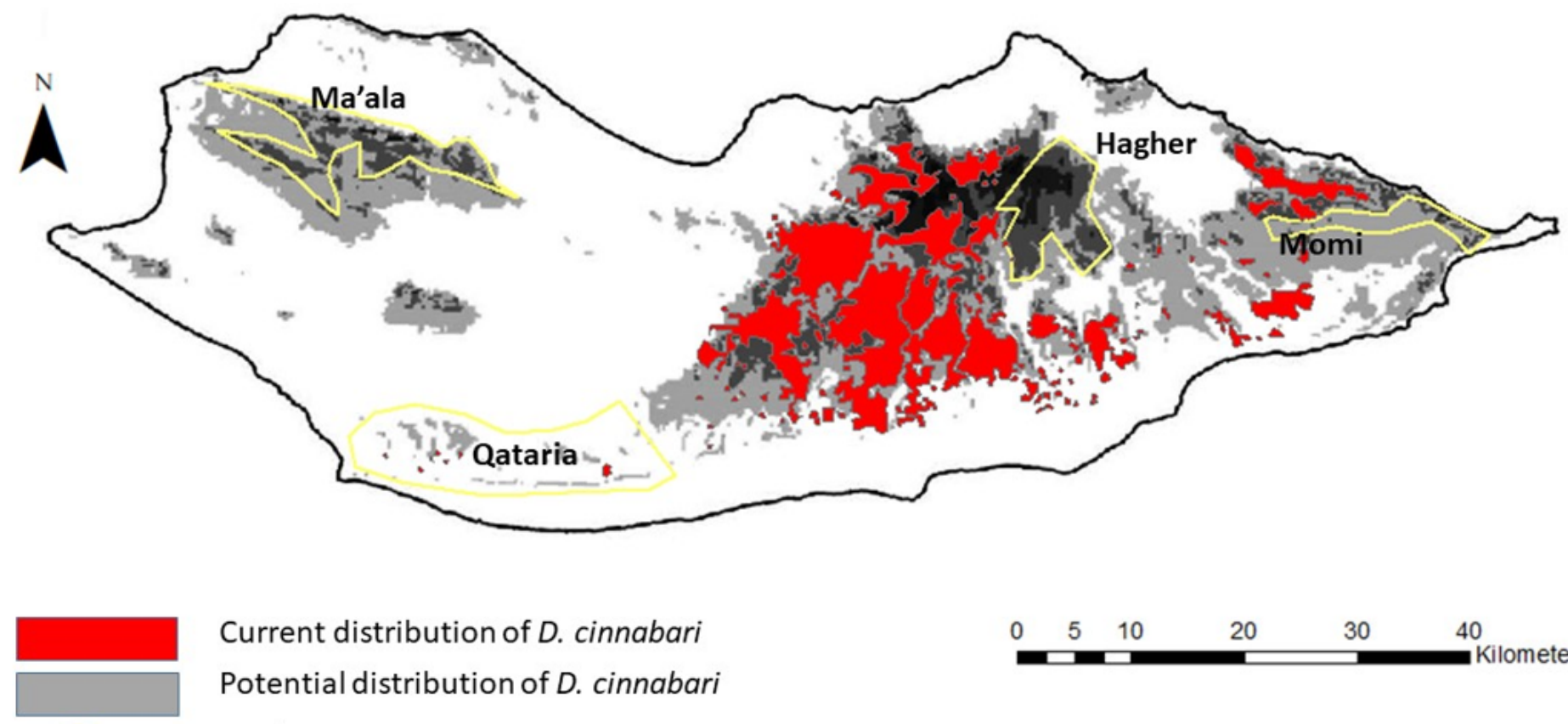

Current distribution of $D$. cinnabari

Potential distribution of $D$. cinnabari

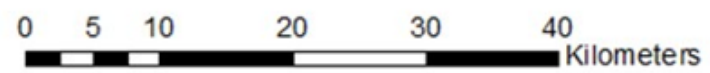

Study areas

\section{Figure 1}

Map showing the study areas (Hagher, Momi, Qatanin, Ma'ala) in integrating two maps with the current and potential distribution of D. cinnabari according to Maděra et al. (2019)[47] and Attorre et al. (2007) [70], respectively. 


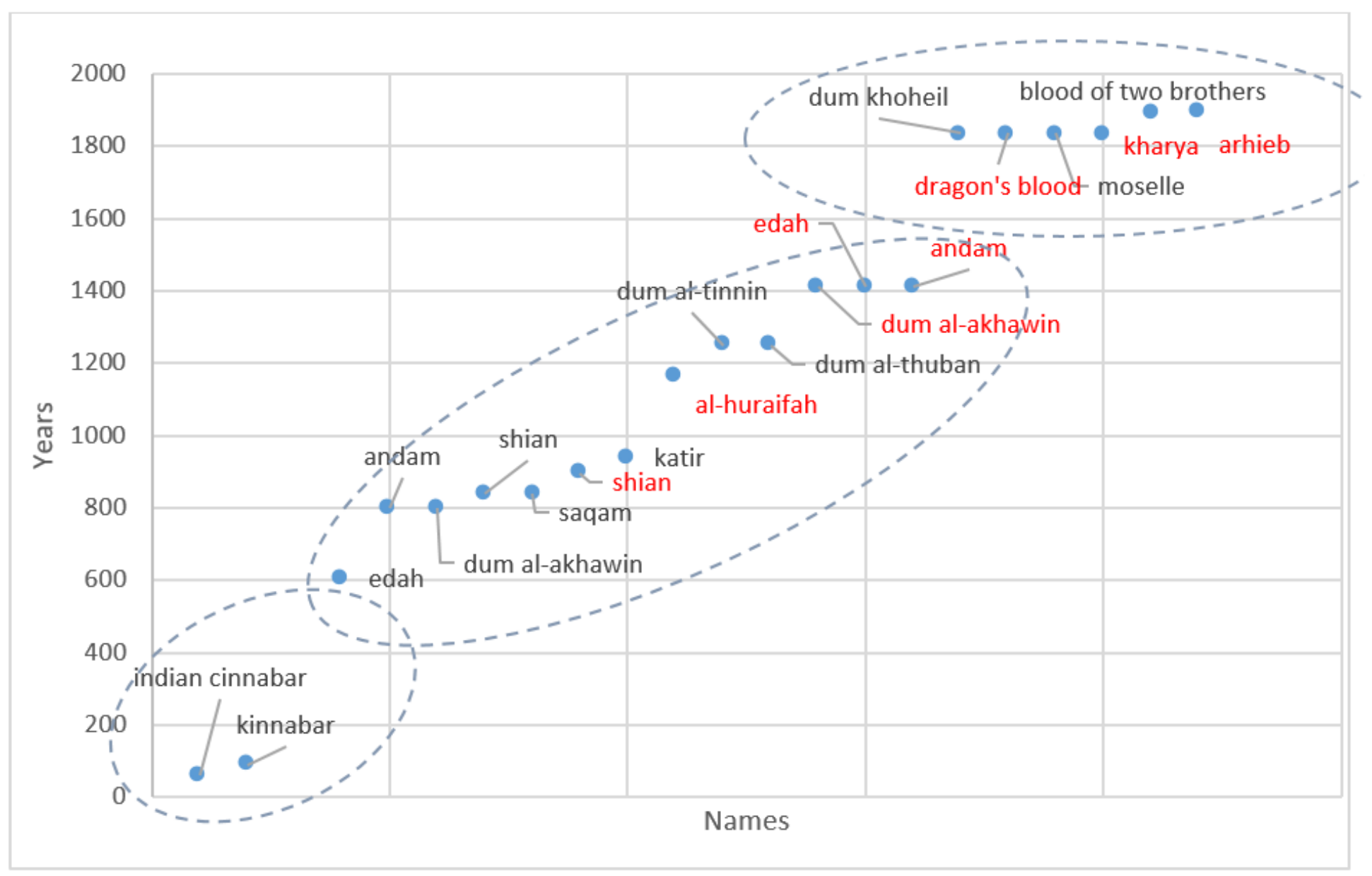

\section{Figure 2}

Map showing the study areas (Hagher, Momi, Qatanin, Ma'ala) in integrating two maps with the current and potential distribution of D. cinnabari according to Maděra et al. (2019)[47] and Attorre et al. (2007) [70], respectively. 


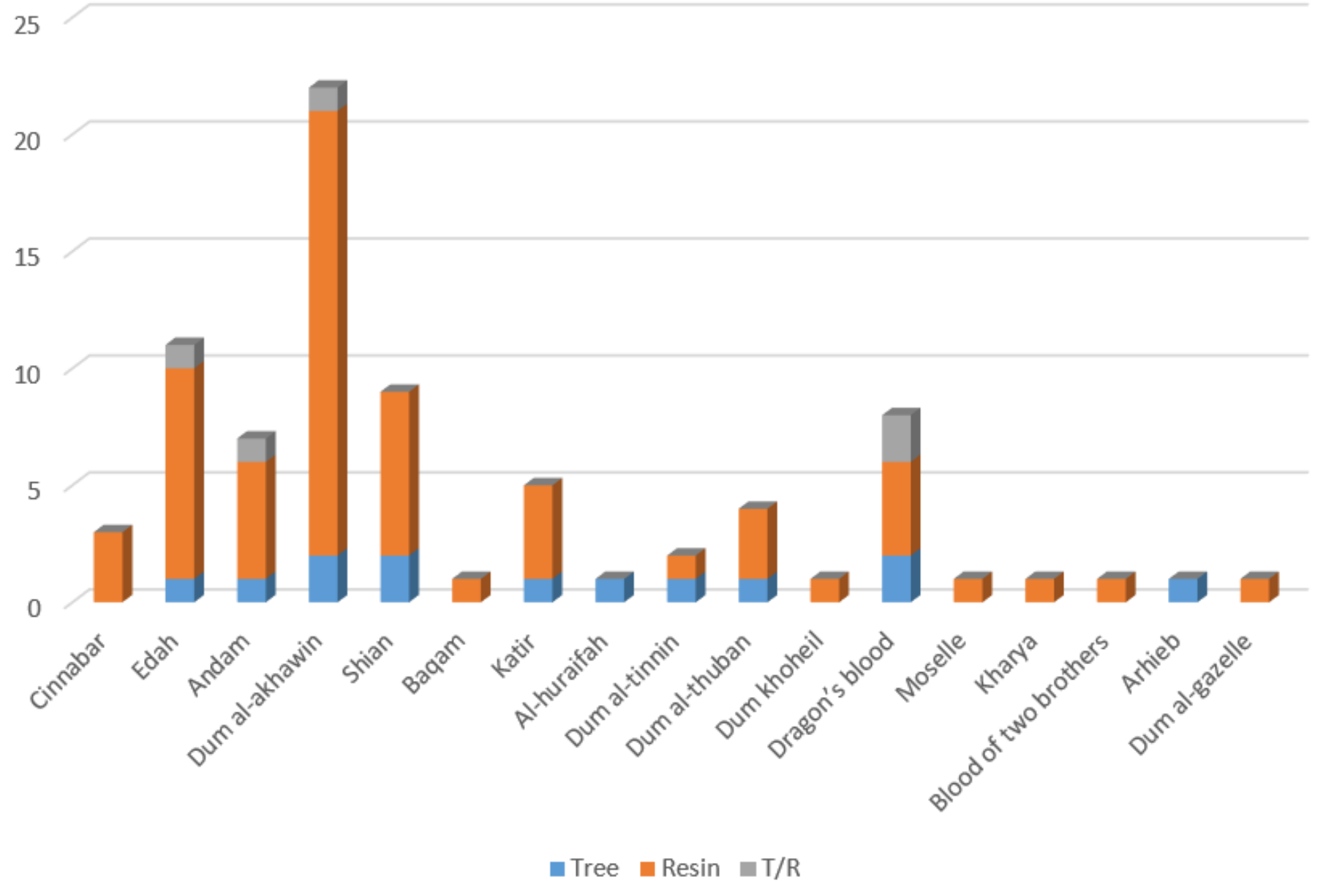

Figure 3

Frequency of appearing of dragon's blood (tree and resin) names in literature from 1st century AD to 2000 $A D, T / R$ means that the name is given to both the tree and to the resin, references listed in Table 2. 


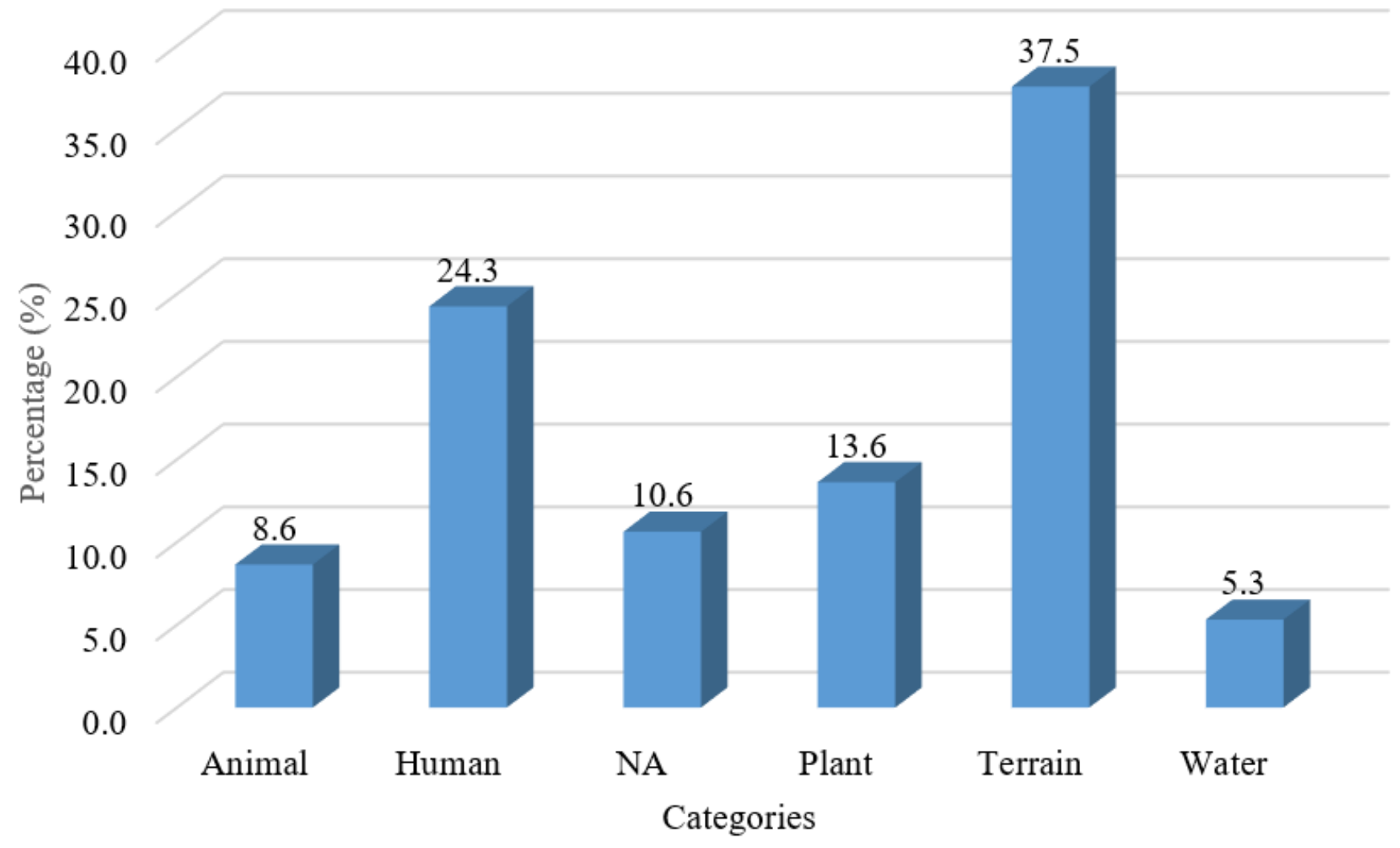

Figure 4

Frequency of toponym categories in the four selected areas on Socotra, summary of 301 names. 


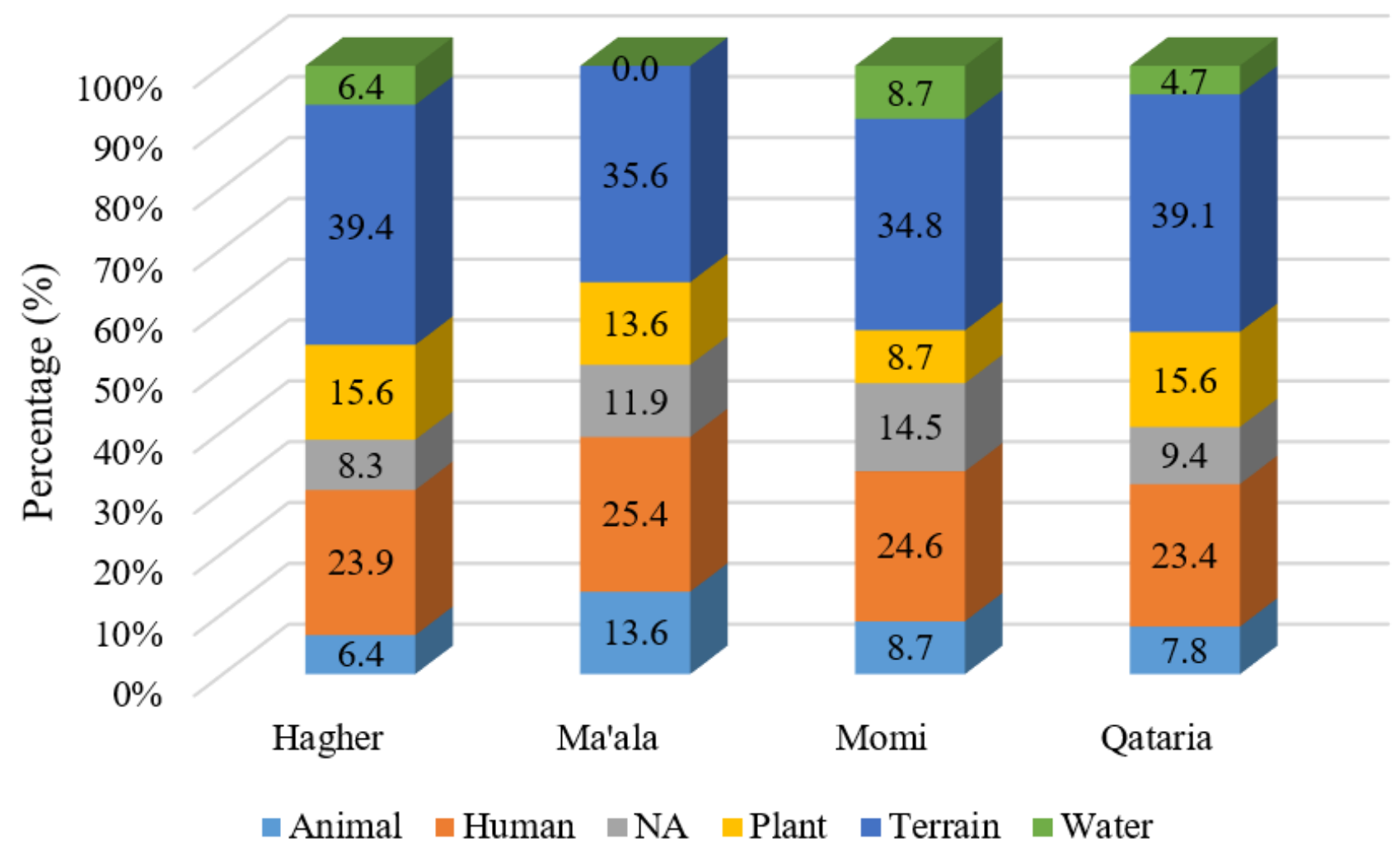

Figure 5

Frequency of toponym categories within each area 


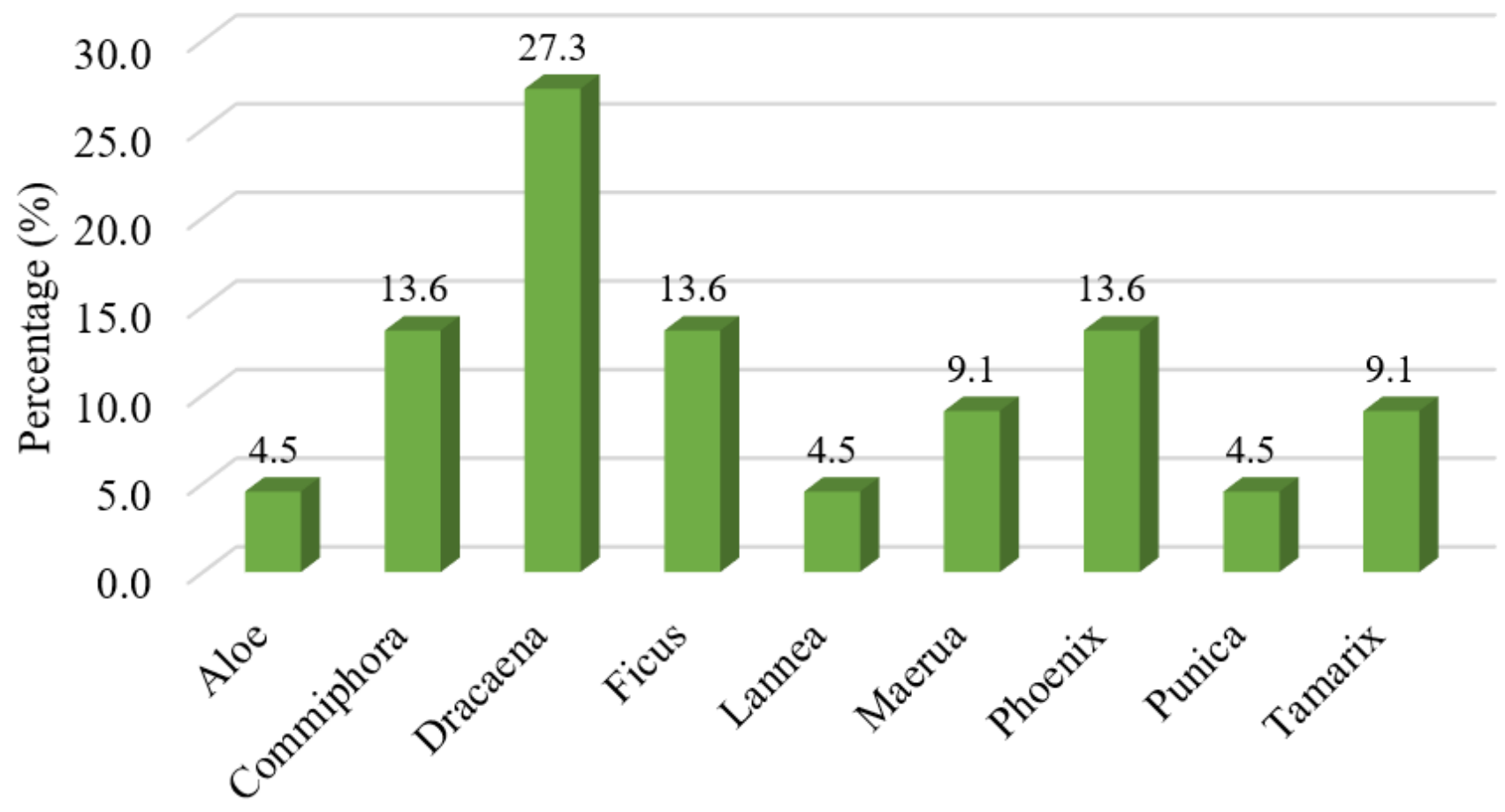

Identified Plant species

\section{Figure 6}

Frequency of phytotoponyms in the subcategory referring to identified plants (genus/species), including Dracaena cinnabari ( $27.3 \%$ of the subcategory).

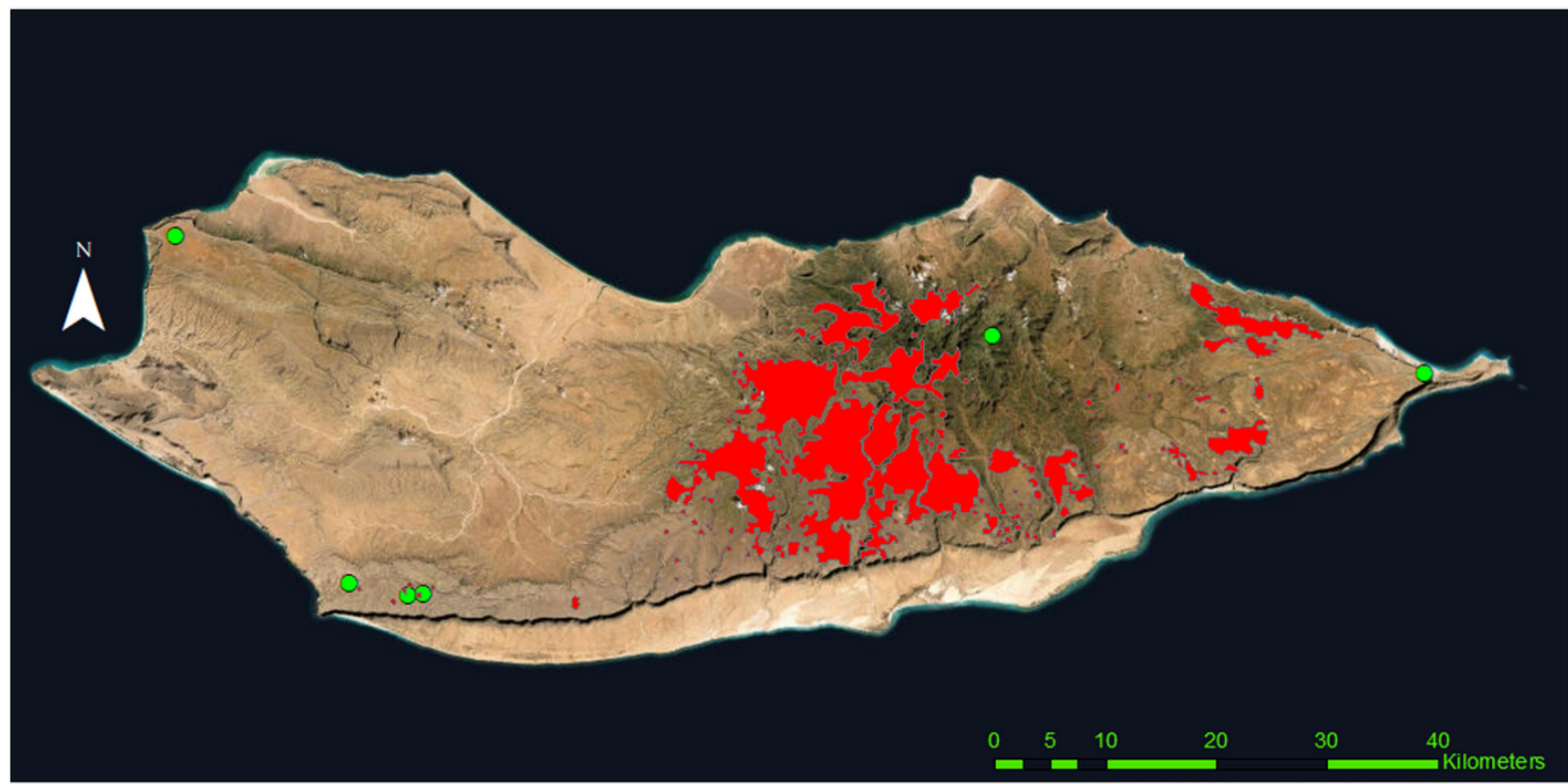




\section{Figure 7}

The map of distribution of the toponyms related to the D. cinnabari tree (green circles) in Socotra Island. In red, the current distribution of D. cinnabari by Madera et al. (2019).

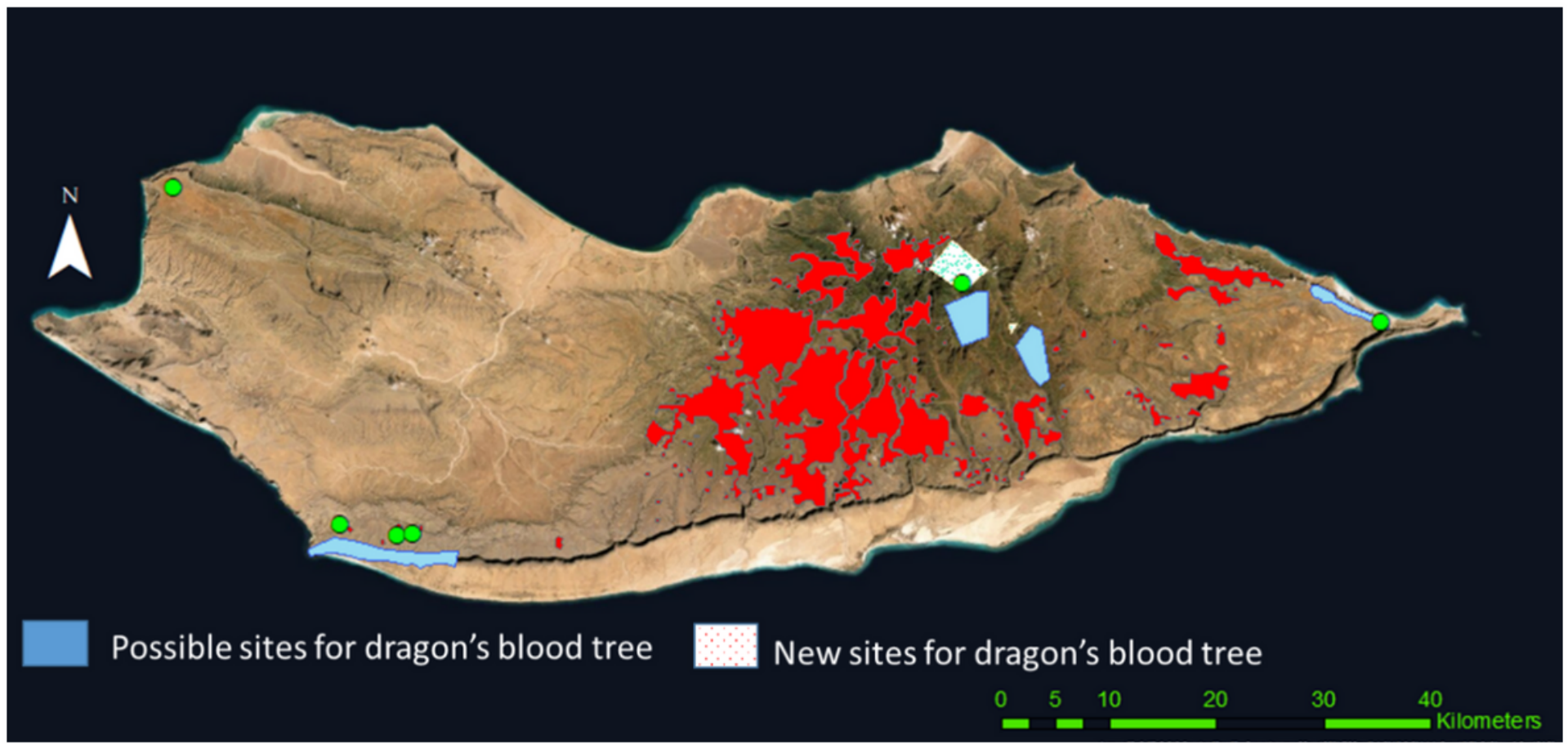

\section{Figure 8}

Map of new sites of dragon's blood tree from the field work (white polygon with dots), not published by Maděra et al. 2019 (red color) and possible sites for dragon's blood tree according to the local community for further field research (blue polygons), green points (toponyms related to D. cinnabari). 